\title{
Teatro griego antiguo y teatro indio: su origen en danzas corales que miman antiguos mitos
}

\author{
Francisco Rodríguez Adrados \\ Real Academia Española

\begin{abstract}
Ancient Greek and Indian theatres: their origin in choral dances, which represent old myths by means of mimesis
\end{abstract}

\begin{abstract}
En relación con el tema del origen del teatro griego, de la tragedia sobre todo, el autor insiste en la teoría ya publicada por él repetidas veces, de que procede de danzas corales, religiosas, que representan, mediante una mímesis antigua, mitos. El origen en la lírica coral lo propuso ya Aristóteles, pero en forma insuficiente. El autor lleva más lejos, en el detalle, su teoría y habla de la necesidad de partir de datos de las mismas obras griegas: unidades líricas y su organización en obras teatrales añadiendo a los corales la recitación de los coreutas. Confirma todo esto con hechos paralelos descubiertos en el teatro indio por el profesor Gupt, de Nueva Delhi, y la correlación que él establece entre estos datos y los griegos: danza mimética, rito y mito.
\end{abstract}

Palabras clave: teatro griego; teatro indio; danzas corales; orígenes del teatro.
Regarding the subject of the origin of Greek theatre, especially of tragedy, the author insists in defending the theory already published by him in several occasions, according to which it would have been originated in choral, religious dances, which represent myths by means of an old mimesis. Aristotle suggested choral lyric as its origin, but he did it in a superficial manner. The author develops his theory in detail and speaks of the necessity of using information found in Greek theatre plays themselves: lyric unities and their organization as theatre plays, adding the recitation of the choreutae to choral passages. He proves all this with parallel facts found in Indian theatre by Prof. Gupt, from New Delhi, as well as with the correlation that the author sets between these evidences and the Greek ones: mimetic dance, rite and myth.

Key words: ancient Greek theatre; ancient Indian theatre; choral dances; origin of theatre.

\section{De Aristóteles al método comparativo: aciertos e insuficiencias sobre el tema de los origenes}

No ignora ninguno de los estudiosos que se han interesado en España por el teatro griego antiguo la tesis que llevo presentando en esta revista desde 1967 (Adrados 1967; cf. 1969) y luego en libro desde 1972 (Adrados 1972, ${ }^{2} 1983$ ): que el teatro griego viene de danzas sacrales miméticas, es decir, de los coros, 
los corifeos y los miembros de coros de celebraciones sacrales. Dentro de la tragedia, los coros han seguido siendo siempre así, encarnan colectividades; pero los corifeos y coreutas han pasado a convertirse, individualmente, en personajes que raramente cantan, casi siempre recitan y dialogan en trímetros yámbicos, raramente en tetrámetros trocaicos. Y que, de entre las doctrinas de Aristóteles, es cierta la de que la tragedia viene de los exarcontes, jefes de coro, de la lírica coral, que en un momento dado, convertidos en corifeos, pasaron a dialogar con los actores, antiguos coreutas, en recitado yámbico o trocaico (con coreutas convertidos en personajes de la obra).

Sobre esto he escrito, tras aquel libro, diversos trabajos en España y fuera (cf. Adrados 1974; 1987; 1996; 1999; 2005; 2008). Parece ser que nadie los ha aceptado o refutado, no los citan, como sucede con la mayor parte de los estudios de Filología Clásica que se publican fuera de los grandes centros tradicionales, cuya producción, por otra parte, es muchas veces repetitiva. Porque hay en la Filología Clásica actual mucho de pasividad; si alguien propone algo nuevo que intenta superar las viejas posiciones, parece que el tema no interesa, ni siquiera es refutado, muchos prefieren seguir la rutina. $\mathrm{O}$ buscar temas marginales.

Pero es increíble que el coro trágico y el cómico fueran en el origen puramente dionisiacos, como dice Aristóteles al reducir los corales originales del teatro a los ditirámbicos y los fálicos y al decir que la tragedia viene del coro de sátiros (cf. Arist., Po. 1449a): esto va contra los datos, son una ínfima minoría las tragedias de tema dionisiaco; y entre los corales dionisiacos mismos los dos géneros que el Estagirita cita son una parte mínima.

Y la doctrina de la entelequia, esto es, de que hay una «naturaleza» propia de cada género o cosa, presente desde el comienzo y que acaba por imponerse y llevar cada entidad, la tragedia y la comedia en nuestro caso, a su «verdadera naturaleza», es un verdadero mito, nadie cree ya en eso. No hay una naturaleza original que crece y se impone, la physis se crea y evoluciona con el tiempo, por causa de múltiples factores. No todo nos viene de una naturaleza inicial.

Y los grotescos «ditirambos de sátiros» de Wilamowitz jamás existieron, el phallikón es un coro dionisiaco entre otros múltiples, igual el ditirambo, no todo es el juego entre piezas iniciales que simplemente crecen.

A lo íntimo de la tragedia no llegó nunca Aristóteles, hijo de una época poco religiosa. Porque es una muy limitada definición el decir que la tragedia

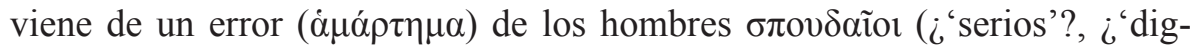




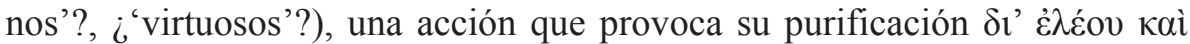

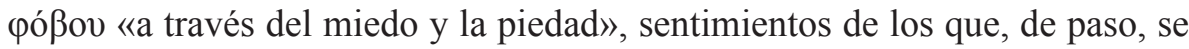
liberan los espectadores (Arist., Po. 1449 21 ss). No se trata sólo de un cambio que impresiona al público gracias a su solemne presentación con ayuda de la palabra, la música, la mímesis del error.

A la íntima comprensión de la hybris, que arrastra de una forma irracional, casi demoníaca, al hombre noble pero olvidado de toda racionalidad, arrastrado inconsciente, pasionalmente al olvido de los límites de todo poder, de todo saber humano, no llega Aristóteles. Es un dato religioso que no comprende.

Aristóteles tiene grandes méritos: haber acabado con la teoría de las Ideas, haber introducido la búsqueda y estudio sistemático de datos y hechos, haber destacado en la definición y la clasificación de los mismos. Pero todo lo misterioso, profundo, religioso se le escapa: y es precisamente de eso de lo que se ocupa la tragedia. Su doctrina de la entelequia, de las causas finales, etc., en la que él se apoya, por ejemplo, en el tema de la tragedia, ha sido rechazada por la ciencia, aunque a él y a muchos los haya seducido a lo largo de la historia.

Pero, de todos modos fue mérito suyo el haber postulado que la tragedia venía de corales que cantaban mitos relacionados con la conducta y destino de los hombres. Tiene también el mérito Aristóteles de haber evitado, al menos, la extraña hipótesis del ditirambo de sátiros.

Son varios los estudiosos modernos que han comparado la tragedia griega con celebraciones religiosas de diversos pueblos. Fueron estudiadas ya por Frazer en The Golden Bough. Así, entre otros, lo propusieron Ridgeway y Cornford. El terrible espectáculo de la gloria y, luego, la caída de héroes entre humanos y divinos no es cosa sólo de los griegos, se da también en celebraciones religiosas de muchos pueblos. Pero esas hipótesis se han presentado con demasiado apriorismo, demasiada falta de estudios filológicos de los datos de cada caso. Sobre todo en el nuestro, el de la tragedia griega $^{1}$.

Pero es claro que hay una evolución de coros y coreutas en diversas celebraciones religiosas de diversos pueblos. En ellas, si el personaje central era tal dios o tal héroe, el coro estaba formado por sus devotos, amigos o servidores y algunos de ellos pasaron, con el tiempo, a convertirse en personajes

\footnotetext{
${ }^{1}$ Véase mi libro ya citado, Adrados 1972, p. 68 ss.
} 
con nombre propio que intervenían en la acción. De otra parte, en el teatro quedaron unidades antiguas (himno, agón, súplica...), propias de algunos de los viejos coros, que luego evolucionaron hacia el diálogo. Es una hipótesis de pura evidencia.

Pero lo que es necesario, llegados a Grecia, para investigar los orígenes del teatro, es estudiar los antiguos tipos de coro que mimaban una acción que estaba siempre dentro de un contexto sacral. Hay que estudiar, para ello, las unidades formales de las tragedias y comedias que se conservan, porque en ellas queda la impronta de lo antiguo, mezclada, claro, con evoluciones recientes. Hay unidades rituales de himno, súplica, agón, treno y otras más que han evolucionado luego de varias maneras.

Todas ellas, junto con el coro y los personajes que intervienen en la acción, el canto y el diálogo, se organizan para crear la obra total, son los distintos segmentos de la misma, hay que ver cómo funcionan.

Ya se ve: todo lo que he expuesto y expongo ahora sobre este tema del origen de la tragedia y de la comedia es una exégesis de lo que hace tiempo vengo exponiendo: se basa en el análisis interno y en la visión de cómo las unidades elementales todavía visibles, las que acabo de citar, se enlazan para desarrollar el argumento. En él, el coro y los personajes antiguos son puestos en escena mediante la mímesis: los cantantes-actores «son» los personajes originarios.

Es el principio de la mímesis, que es universal en representaciones con danza y mímesis en multitud de actuaciones festivas y sacrales, en muchos pueblos primitivos, todavía. Y en otras vivas todavía en fiestas en toda Europa.

Traen a nuestros ojos y oídos corales y episodios en que intervienen un coro y uno o varios actores. Se enlazan para crear una acción total, corresponden a unidades de acción y pasión que están en los orígenes míticos, religiosos, del teatro, plasmados en representaciones festivas diversas. Son como anillos que se encadenan como momentos consecutivos de un argumento: éste contiene acción, angustia, duda, súplica, lucha, pasión, muerte, triunfo otras veces. Crean una serie ritual que expresa, duplica diríamos, la acción humana en los antiguos mitos, la presenta ante el público de toda la ciudad. La explican dentro de un marco de fuerzas sacrales.

Esto es lo importante, no Aristóteles, que pese a todo dijo una cosa sensata: que el teatro venía de la lírica danzada por coros religiosos diversos, cuyos exarcontes y coreutas creaban luego el recitado y el diálogo que reproducían o intentaban reproducir el modelo antiguo. 


\section{El teatro indio y la interpretación de Bharat Gupt}

Pero yo no habría caído en la tentación de criticar, como otras veces he hecho, a los que repiten añosas doctrinas que considero insuficientes, si no fuera por un rayo de esperanza: un libro que hace cambiar el panorama. Ha habido un filólogo procedente de un ambiente religioso, el de la India, no de sociedades casi anestesiadas por una mentalidad profana como las de Europa y América, que ha dicho del teatro indio más o menos lo mismo que lo que yo dije del griego.

Es el profesor de Nueva Delhi Bharat Gupt, que ha publicado un libro (Gupt 1994, ${ }^{32006)}$ que aplica al teatro indio, que todavía sobrevive en festividades religiosas, la idea de que procede de viejas danzas corales que representan mitos de fondo religioso. Me refiero al libro Dramatic Concepts, Greek and Indian. A Study of Poetics and Nātyaśästra².

Se apoya en la religiosidad india, todavía bien visible en el teatro y en toda la vida de la India, yo en la griega antigua, la de una sociedad todavía anclada en el rito y el mito. Sobre todo, en el momento inicial de Tespis y todavía, luego, más menos, en el de Esquilo, Sófocles, Eurípides y Aristófanes.

Pero las cosas variaron en Atenas con la sofística, ya sabemos. Y Aristóteles tuvo un acierto, ya dije, pero también caídas, es grotesco que los atenienses fueran a presenciar la tragedia para liberarse del miedo y la piedad, como los que iban al sofá del doctor Freud. Iban a presenciar un espectáculo nada trivial, a dejarse penetrar por ojos y oídos por antiguos sucesos humanos que a todo hombre afectan. Le hacen recordar, aprender en un contexto de fuerzas entre divinas y humanas.

El profesor Bharat Gupt cita profusamente mi libro, cuya primera edición es de 1972 (y hay, ya dije, presentaciones anteriores de mis ideas) y que él leyó en la edición inglesa, publicada en Brill, Leiden, 1975. Fue él quien me envió el suyo. El estudia en detalle los datos indios, pero hace constar que son sensiblemente iguales a los griegos. El teatro indio y el griego son paralelos, son presentaciones corales y dramáticas de fiestas de fondo religioso.

2 Véase una exposición por Bharat Gupt de la doctrina del Nātyaśāstra sobre la antigua danza teatral india en Nandusnotebook 〈http://nandusnotebook.wordpress.com/2012/02/11/ natyasastra-workshop-at-kalashetra-by-bharat-gupt/s. 
Cita pasajes míos paralelos a sus propias ideas, pasajes como éste:

Todo ritual dramático está basado en la danza ... es al tiempo liturgia y diversión y acción eficaz para rechazar el mal y promover la fertilidad, la guerra o la caza. En el ritual el ser humano, incluso sin máscara, es trasformado, en comunión con la vida de animales o dioses o de sus antepasados (Gupt 2006, p. 67).

Por supuesto, mi exposición ha podido ayudarle a aceptar las interpretaciones religiosas y mítica, aceptarlas para la sociedad india antigua y moderna, yo lo había hecho para la griega antigua. El profesor Gupt captó inmediatamente el paralelismo de las situaciones y la evolución histórica de los teatros indio y griego, citó en su libro el mío, se puso en comunicación conmigo, ya dije.

En realidad yo proponía ya que ese ambiente religioso, ritual, que colocaba en el origen del teatro griego, tragedia y comedia, era no sólo griego, sino general en muchas culturas antiguas, incluso modernas, que no han perdido los antiguos lazos con el mundo de lo religioso. Ahora el Dr. Gupt se refiere concretamente a la India. Grecia y la India, después de todo, tienen raíces comunes, raíces indoeuropeas.

$\mathrm{Y}$, efectivamente, la India conservaba y conserva vivo un mundo con sensibilidad religiosa ante el mito y ante la danza sacral, que lo traía a los ojos y los oídos de todos. India vivía y vive, al menos en parte, inmersa en religión y mito vivo, en lírica cantada abierta a antiguos y modernos prototipos, a los antiguos dioses. No vive en un mundo puramente profano, como en general sucede en Europa y América. Y el profesor Gupt ha visto, sentido, igual que yo, la esencia de esa antigua lírica religiosa que contaba historias antiguas, comunicaba con un público que todavía tenía acceso a ese mundo, lo sentía como propio.

En cierto modo, España, con sus autos sacramentales, sus procesiones, sus representaciones religiosas de la Pasión, tiene todavía acceso a un mundo semejante. Y en la Edad Media surgió un semiteatro - he hablado de él en otros lugares (cf. Adrados 1972, p. 501 ss.) — que procedía de antiguos mitos y rituales. Un semiteatro a veces con temas carnavalescos o procedente de la fiesta de las Mayas o en Italia del ciclo de Arlequín, en varios lugares de las celebraciones de Moros y Cristianos (Moresca en Italia, Morrish Dance en Inglaterra). También puede citarse el Jeu de la Feuillée de Adam de la Halle, en el siglo XIII, en Francia, con un Arlequín claramente demoníaco o repre- 
sentaciones de Robin Hood y Queen Marion en Inglaterra, la Befanata en Italia, etc.

Y habría que hablar de representaciones teatrales o semiteatrales de ciclos carnavalescos y otros más que provienen de religiones precristianas y que hoy son folklóricos, perviven en la fiestas ${ }^{3}$.

Añádase la recepción en España y otros lugares de pasajes de la Pasión, así como otros más que han sido teatralizados desde la Edad Media y son representados en muchos lugares en España. Recuérdese, entre otras representaciones, ya en la Edad Media, la Visitatio sepulchri (siglo XI, Silos) o el Officium pastorum (siglos XI o XII, Huesca), todavía en latín. Y, ya con texto castellano, las representaciones en la catedral de Toledo y el Auto de los Reyes Magos (también en Toledo, siglo XIII ${ }^{4}$ ). Y los Misterios en Francia, más tarde los Autos sacramentales en España. También hay datos de otros países de Europa (cf. Kindermann 1980).

Nadie debería extrañarse de que, tratando de explicar los antiguos teatros griego e indio, yo hable de la Edad Media. Lo hago porque son hechos paralelos, aunque sea en diferentes épocas, en diferentes culturas: el nacimiento, a partir de ritos y textos religiosos, de representaciones miméticas de carácter entre religioso y festivo. La Edad Media es un nuevo giro, una nueva cultura que nació tras el hundimiento de la antigua: creó hechos literarios más o menos paralelos, no sólo el teatro, también la épica y la lírica.

Pues bien, volviendo a la antigua España, las procesiones son también representaciones de viejos temas cristianos. Y sigue habiendo, en distintos lugares, representaciones de pasajes o temas evangélicos y también marianos, por ejemplo, la representación en Elche en el día de la Asunción.

Volvamos a Atenas. Allí, el público iba a ver, sentir el teatro, no a purgarse de nada, sino a contemplar los antiguos mitos presentados al nivel humano, a impregnarse de ejemplos omnipresentes de la vida y la muerte y el dolor y la risa, de esencias religiosas, y al tiempo humanas, que le penetraban.

Los teóricos como Aristóteles eran ya sordos a todo esto. E igual tantos eruditos modernos pertenecen a otro mundo ya.

${ }^{3}$ Véanse varios libros de J. Caro Baroja como los de 1963, 1979 y 1974. También, entre una bibliografía inabarcable, Epton 1968; Álvarez de Miranda 1962; Bajtin 1971; Silva y Roman 2000; Ladero 2004.

${ }^{4}$ Véanse muchos más datos en Lázaro Carreter 1970. También el Auto de la Pasión, de Alonso del Campo, descubierto recientemente. 
No insisto más. Hay que, simplemente, dejarse penetrar por esas antiguas esencias, no tan distantes, a veces, de fiestas y ritos de pueblos primitivos y de otros de la Edad Media que fueron creando un teatro germinal no distante del teatro y de la sensibilidad de los antiguos griegos y los indios y, a veces, del hombre común de nuestro tiempo, que puede todavía dejarse arrastrar, también él, por un dolor y una risa que vienen del viejo mundo sacral que a veces a todos nos penetra ${ }^{5}$.

Pero si escribo esto es para dos cosas, insisto en lo que ya dije. Primera, para lamentarme de tanta incomprensión sobre el tema de los orígenes del teatro: son todavía aceptadas hoy grandes dosis de Aristóteles y Wilamowitz, grandes dosis de desconfianza en quienes escriben desde países como el nuestro, que no tienen tanta tradición filológica pero no tienen por qué no pensar libremente, aportando paralelos y datos. Pero quizás tengamos más tradición religiosa y popular que otros países y menos fe dogmática en las propuestas de Aristóteles, Wilamowitz y otros dogmáticos.

Debemos atrevernos a mirar directamente a las piezas teatrales antiguas, a hacerlas hablar, también, sobre el tema de los orígenes.

Pero es más importante la segunda cosa. De tanta incomprensión le consuela a uno una cosa: puedo presentar hoy el paralelo de un filólogo que, lejos de nuestros ambientes filológicos, se ha sentido penetrar por el ambiente religioso, musical, mítico de la tragedia de su pueblo, la India. Ha visto que, incluso en el ambiente actual en la India, inevitablemente penetrada por la cultura laica de Europa y América, existe - allí, en su país - un teatro en que todavía son importantes el coro, el mito, la religión y ha postulado que esto es lo antiguo en el teatro, evolucionando luego más o menos, pero dejando huella de su antigua esencia. Me refiero al profesor Bharat, ya he hablado de él. Porque en la India los personajes del antiguo teatro, sobre todo los derivados del Ramayana, están vivos cada día en mil representaciones.

El Katakali, todavía vivo también, puede presenciarse todavía: es un teatro con máscaras, musical, con los antiguos temas religiosos y heroicos. Quedé impresionado cuando lo presencié en Bombay, hace ya mucho tiempo ${ }^{6}$.

Esto es lo que ha propuesto el profesor Gupt en su libro de 1994, muy posterior a mis elucubraciones sobre el teatro griego. Substancialmente deci-

\footnotetext{
${ }^{5}$ Sobre estos rituales véase Adrados 1972 p. 495 ss.

${ }^{6}$ En Adrados 1972, p. 539 ss. pueden encontrarse más datos sobre el teatro indio tradicional y otros teatros semejantes.
} 
mos lo mismo, no era, pues, tan desechable aquella hipótesis. Pero querría señalar, primero, que este teatro indio de los siglos III y IV d. C., que tiene orígenes semejantes al griego, como acabo de decir, surgió independientemente del griego: en un país lejano y con una diferencia temporal notable. El griego procede del siglo VI a. C., como se sabe; y los precedentes del indio los localiza Gupt con ayuda del Nātyaśāstra o "Libro de los danzarines» (o «actores», nātya tiene los dos significados), cuya fecha probable es el siglo II d. C.

Por lo demás, griegos e indios descienden, como se sabe, de la misma matriz indoeuropea que está presente tanto en la epopeya como en la lírica coral, de la que desciende, en ambos lugares, el teatro. No son raros los elementos comunes, por tanto. Ni los diferenciales, tampoco.

\section{Diferencias del teatro indio y del griego}

Es muy distinto el teatro indio, sin embargo, del griego en un punto: no presenta oposición entre tragedia y comedia. En India hay un género único, no dos o tres. Y no está presente allí el espíritu de la tragedia: las obras indias que se conservan nos traen un ambiente indio palacial, con elementos religiosos y míticos, hay una trama sobre todo erótica en la que intervienen el Rey y la Reina, las mujeres del palacio y el bufón. Son obras de entretenimiento, en ellas, tras dificultades y conflictos, hay un final feliz. Esto en Grecia solo sucede en la comedia; en la tragedia al final de la trilogía, no en las piezas aisladas.

Y la tragedia es sólo griega, en cualquier lugar del mundo en que se escriba, siempre depende, directa o indirectamente, de un influjo griego. Desapareció fuera de Grecia, salvo en los ejemplos latinos que la imitan (la tragedia cothurnata en época arcaica, Séneca, creador de un género artificial) y en resurrecciones del género, desde el Renacimiento, a partir de los clásicos griegos, así en la Celestina (véase Adrados 1996). Pienso también que algunas comedias clásicas españolas son en realidad tragedias. Hay luego tragedia en Shakespeare, Racine, algunos dramaturgos contemporáneos. Siempre depende, directa o indirectamente, de los griegos. Y, en cambio, en el teatro indio no hay tragedia.

Véase, por ejemplo, cómo en Las Traquinias de Sófocles el enfrentamiento entre las dos mujeres, la vieja y la joven, acaba en tragedia, mientras que una situación idéntica en Ratnâvalī acaba en comedia. No hay nada compa- 
rable en la India a la tragedia griega; en realidad a las obras teatrales indias, descendientes desde luego de la lírica y danzas populares de origen religioso, más bien las llamaríamos comedias — aparte de que es muy posible, creo, que hayan recibido influjos de la comedia latina-.

El libro del profesor Gupt que he citado refuta con razón propuestas de que ha habido influencia de la Poética de Aristóteles en Bharata Muni, autor o supuesto autor del Nātyaśāstra. Insiste también, con razón, en que el teatro indio es una hieropraxis, un acto de culto (igual el griego). Por otra parte, el teatro indio se representaba en un ambiente regio y palaciego, esto no tiene nada que ver con Grecia, incluso cuando intervenían reyes. La tragedia griega se desarrolla entre héroes míticos, no entre reyes, reinas, concubinas, el bufón, etc., no diferentes de los contemporáneos, como la india.

En India hay que pensar, de otra parte, que el Katakali y otros teatros populares surgieron también ellos de la lírica mimética, pero independientemente del teatro a que ahora me estoy refiriendo.

De esto hablé en mi libro con cierta extensión, en relación con Grecia: del proceso en que se pasa de enfrentamientos entre seres míticos o demoníacos y sus coros al verdadero teatro griego.

A la comunidad de origen del teatro griego y el indio - y otros teatros y preteatros - en una danza que es mítica y mimética se refieren estas páginas. Pero también a las diferencias.

A ellas debo añadir una más: el teatro indio es unitario, comporta incidencias dolorosas con un final feliz. El griego estuvo escindido, como es sabido, entre tragedia y comedia. Los griegos optaron por separar la tragedia, la pusieron en el centro; y lo que no fue tragedia se hizo comedia, como en ciertas celebraciones populares. Fue un invento posterior al de la tragedia, las fuentes están de acuerdo en esto.

Del conjunto original de danzas que reflejaban el mundo complejo de la vida humana, separaron las versiones que terminaban de manera trágica, como ahora decimos. Y, posteriormente, todos los argumentos no trágicos fueron organizados en un género aparte, el género cómico. Es simétrico al trágico en muchas cosas, casi lo imita, pero con un acción final diferente, opuesta.

Fue un tanto artificioso el proceder de los griegos: la vida humana es trágica y cómica y hubo en fecha posterior obras que unían, efectivamente, tragedia y comedia. La Celestina y varias obras de Shakespeare, por ejemplo. 
Puede pensarse de dos modos en torno a esto, pero los griegos prefirieron destacar los aspectos trágicos de la vida humana en un género aparte. Los aspectos cómicos los relegaron a otro género aparte: primero al drama satírico, que mantenía sin embargo los personajes de la tragedia; luego, decididamente, crearon la comedia, con un tema burlesco que incluye el triunfo de un nuevo tipo de héroe, el héroe cómico.

En la epopeya y en la lírica, encontramos momentos trágicos, otros cómicos, otros que no encajan en esta clasificación. El teatro griego fue un invento muy especial. Comenzó en forma paralela a rituales diversos, con varios momentos. Como en la India. Pero los griegos crearon dos teatros: separaron el trágico, quisieron la tragedia pura. Luego la complementaron con la comedia.

\section{BibLIOGRAFÍA}

Adrados, F. R. 1967: «K $\Omega \mathrm{MO} \Sigma$, K $\Omega \mathrm{M} \Omega \mathrm{I} \Delta \mathrm{IA}$, ТРАГ $\Omega \mathrm{I} \Delta \mathrm{IA}$. Sobre los orígenes griegos del teatro», Emerita 35, pp. 249-264.

Adrados, F. R. 1969: «Ideas metodológicas para el estudio de la evolución y sentido del teatro griego», Revista de la Universidad de Madrid 18, pp. 299-319.

Adrados, F. R. 1972: Fiesta, Comedia y Tragedia. Sobre los orígenes griegos del teatro, Barcelona, Planeta (traducción inglesa: Festival, Comedy and Tragedy, Leiden, Brill, 1975); nueva edición en Madrid, Alianza Universidad, 1983.

Adrados, F. R. 1974: «The agon and the origin of tragic chorus», en Heller, J. L. (ed.), Serta Turyniana. Studies in Greek Literature and Palaeography in honor of Alexander Turyn, Urbana-Chicago-Londres, University of Illionis Press, pp. 108-121.

Adrados, F. R. 1987: «Rite, mythe et théâtre en Grèce ancienne», en GhironBistagne, P. (ed.), Anthropologie et Théâtre antique. Actes du colloque international de Montpellier (6-8 mars 1986), Cahiers du GITA 3, Montpellier, Centre National des Lettres, pp. 37-52 (recogido en español en Adrados 1999, pp. 29-54).

Adrados, F. R. 1996: «El origen del teatro español en Salamanca», en Salamanca y la Literatura. Ciclo de conferencias pronunciadas en Fundación Ramón Areces (Febrero 1996), Madrid, Fundación Ramón Areces, pp. 13-38 (recogido en Adrados 1999, pp. 264-286).

Adrados, F. R. 1999: Del teatro griego al teatro de hoy, Madrid, Alianza.

Adrados, F. R. 2005: «Le origini della tragedia: ¿Aristotele o ricostruzione interna e paragone?», en Grisolia, R. y Rispoli, G. M. (eds.), Il personaggio e la maschera. Atti del Convegno Internazionale di Studi, Nápoles, Naus, pp. 95-102. 
Adrados, F. R. 2008: «¿Aristóteles o reconstrucción interna y comparación? Sobre los orígenes de la tragedia», en Doménech, F. (ed.), Teatro español. Autores clásicos y modernos. Homenaje a Ricardo Doménech, Madrid, Fundamentos, pp. 341-350.

Álvarez de Miranda, A. 1962: Ritos y juegos del toro, Madrid, Taurus.

Bajtin, M. 1971: La cultura popular en la Edad Media y el Renacimiento, Barcelona, Barral.

Caro Baroja, J. 1963: El Carnaval, Madrid, Taurus.

Caro Baroja, J. 1974: Teatro popular y magia, Madrid, Revista de Occidente.

Caro Baroja, J. 1979: La estación del amor, Madrid, Taurus.

Epton, N. 1968: Spanish Fiestas. Including romerías, excluding bullfights, Londres, Casell.

Gupt, B. 1994 [32006]: Dramatic Concepts, Greek and Indian. A Study of Poetics and Nātyaśāstra, Nueva Delhi.

Kindermann, H. 1980: Theaterpublicum des Mittelalters, Salzburgo, Otto Müller.

Ladero, M. Á. 2004: Las fiestas en la cultura medieval, Barcelona, Mondadori.

Lázaro Carreter, F. 1970: Teatro Medieval, Madrid, Castalia.

Silva, H. y Roman, S. 2000: El libro de las tradiciones, Barcelona, Robinbook.

Fecha de recepción de la primera versión del artículo: 29/12/2011

Fecha de aceptación: 17/01/2012

Fecha de recepción de la versión definitiva del artículo: 26/02/2012 